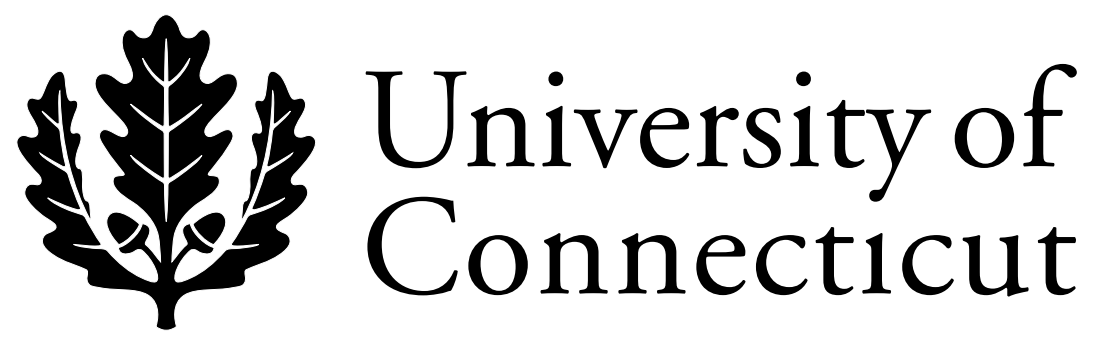

Department of Economics Working Paper Series

\title{
Ottoman Tax Registers (Tahrir Defterleri)
}

Metin M. Cosgel

University of Connecticut

Working Paper 2002-47

October 2002

341 Mansfield Road, Unit 1063

Storrs, CT 06269-1063

Phone: (860) 486-3022

Fax: (860) 486-4463

http://www.econ.uconn.edu/ 


\begin{abstract}
There are few historical records that are as rich, extensive, well-preserved, and widely-available as the tax registers of the Ottoman Empire. To obtain current information on the Empire s sources of revenue, the Ottoman government conducted periodic surveys of the lands under its domination and recorded detailed information about tax-paying subjects and taxable resources in registers commonly known as the tahrir defterleri (s. defter). There now exist defters of regions ranging from Anatolia and the Balkans to Syria and Palestine in the south, Georgia in the east, and Hungary and Poland in the north, altogether forming an indispensable series of documents for studying the economic and social history of the Middle East and Eastern Europe in the fifteenth and sixteenth centuries.

Despite the great potential of these documents, they have been surprisingly underutilized in historical research. Researchers have typically limited their use to the construction of local histories of specific regions, rarely employing them in comprehensive quantitative studies or in addressing questions of broader historical significance or larger social scientific relevance. In this article I argue that following two courses of action may eventually change this outcome. By adopting a more optimistic attitude toward the potential of these sources and by using appropriate sampling procedures to gather data, the historian of the Middle East and Eastern Europe may promote the productive use of defters in historical scholarship and push the boundaries of our knowledge of these regions significantly.
\end{abstract}




\section{Ottoman Tax Registers (Tahrir Defterleri)}

There are few historical records that are as rich, extensive, well-preserved, and widelyavailable as the tax registers of the Ottoman Empire. To obtain current information on the empire's sources of revenue, the Ottoman government conducted periodic surveys of the lands under its domination and recorded detailed information about tax-paying subjects and taxable resources in registers called defter-i $h$ ? $k$ ? $n$ ? [imperial register], commonly known as the tahrir defterleri (s. defter). Many of these registers have survived from the fifteenth, sixteenth, and seventeenth centuries to the present, available to researchers in various archives in Turkey and in other countries that were once under Ottoman domination. There now exist defters of regions ranging from Anatolia and the Balkans to Syria and Palestine in the south, Georgia in the east, and Hungary and Poland in the north, altogether forming an indispensable series of documents for studying the economic and social history of the Middle East and Eastern Europe.

Although magnificent and fascinating as historical records, tahrir defters have been surprisingly underutilized in historical scholarship. Researchers have typically limited their use to the construction of local histories of specific regions, rarely addressing questions of broader historical significance or larger social scientific relevance. Similarly, no comprehensive quantitative studies of the Middle East or Eastern Europe have emerged that have taken full advantage of the wealth of information that these documents provide.

The reasons for the underutilization of tahrir defters in scholarship can be grouped into two general categories. The first is the excessively cautious and sometimes even pessimistic attitude that has recently emerged about the potential uses of these documents. Upon discovering their presence and magnitude in archives, historians of the Ottoman Empire were initially very optimistic about the usefulness of these registers for research. Concerned about 
their possible misuses, however, some respected historians at some point set out to outline their "pitfalls and limitations," the consequence of which was a significant shift in attitude (Lowry, 1992). The period of initial optimism gave way to widespread pessimism, contributing to the underutilization of defters in historical scholarship. In the second category of reasons for their underutilization are the various archival, linguistic, and financial obstacles that have limited the researcher's access to these documents and increased the cost of deciphering and processing the information that they contain. These obstacles have often forced researchers to restrict the focus of their investigation topically, temporally, or geographically by using only a limited subset of all available defters.

With the ultimate goal of changing these tendencies and promoting the use of tahrir defters in research, this paper has two objectives. The first is to respond to criticisms of defters as quantitative historical sources. Once viewed properly, some of the perceived problems of these documents may turn out to be advantages. Although the use of these documents is certainly subject to various limitations, these limitations are not qualitatively different from those that apply to other types of historical sources and thus should not be the sole basis for restricting their applicability in research.

The second objective is to propose a method for the efficient extraction of information from the tahrir defters: sampling. In dealing with massive amounts of information, using a representative sample, rather than the whole data, can facilitate comprehensive, large scale studies at a fraction of the cost. Sampling has been a well-known and frequently employed tool at the historian's disposal in dealing with massive amounts of available data. Some of the studies with great impact on historical analyses have relied on sample data, as can be seen in the 
influential studies of slavery, geographic mobility, and population history. ${ }^{1}$ By contrast, studies based on Ottoman defters have generally chosen to deal with the problem of massive data by restricting the focus of investigation to geographically small areas rather than by constructing representative samples of large areas. ${ }^{2}$ Ottoman historians may have refrained from sampling these documents either because they considered sampling as being an unacceptable method of inquiry or because they were simply unfamiliar with the methods of sampling. This paper will discuss the methods and advantages of sampling the tahrir defters, using data from the published defters of Antep, Budun, Kud?s (Jerusalem), and Malatya. ${ }^{3}$ Using conventional methods of sampling and elementary statistical analysis, I will generate subsets of all the units in each of these registers and compare summary statistics between the subsets and entire populations in order to show how properly drawn samples can represent the characteristics of the population. I will also discuss the limitations of sampling and the types of research where sampling would be unlikely to produce reliable and representative results.

\section{TAHRIR DEFTERLERI AND OTTOMAN HISTORIOGRAPHY}

The detailed tax registers in the series, called mufassal defters, recorded for each fiscal unit the numbers and legal status of adult males, approximate amounts of land in use, and estimates of tax revenues from all productive resources and activities. ${ }^{4}$ The Ottomans used these

\footnotetext{
${ }^{1}$ Fogel and Engerman (1974), Thernstrom (1973), Wrigley and Schofield (1981).

${ }^{2}$ One exception is McGowan (1969). Having worked on the whole defter of Sirem for his Ph.D. dissertation, McGowan sampled from three more areas for a comparative study of food supply and taxation on the Middle Danube River.

3 ? zde?er (1988), Kaldy-Nagy (1971), H?tteroth and Abdalfattah (1977), and Yinan? and Elib?y?k (1983).

${ }^{4}$ At the beginning of each province's register was a document called $k ? n ? n n ? m e$, which laid down the basic tax regulations of the province and specified the rates at which each resource was
} 
documents for a variety of purposes, including as official registers to establish legal claims to land, assess the empire's expected tax revenues, and appropriate some of the revenues to the military and administrative officials as remuneration for their services ${ }^{5}$. Because of their value to the administration of the Empire, the Ottoman government took great care to preserve the defters, and over 1,500 of them have survived to the present. ${ }^{6}$ Similar to the English Domesday book but wider in spatial and temporal coverage, they contain such detailed information about the names, status, and economic activities of taxpayers in Ottoman towns and villages that it is difficult to imagine research on Ottoman history of the fifteenth and sixteenth centuries that does not in some way rely on this information. ${ }^{7}$

The defters have been used in numerous ways in Ottoman historiography. One of the earliest and repeatedly practiced forms of scholarship has been the transcription and publication of the whole register(s) of a region in book form. Over twent y defters, of diverse dates and regions, have so far been published in various languages for scholarly use. Although early

to be taxed in different circumstances. For example, the $k$ ? $n$ ?nn?mes specified, often in great detail, the tax rates that depended on the marital and economic status of peasants and the rates at which different types of grains, trees, animals, mills, and so on were to be taxed. See ?nalc $\mathrm{k}$ (1960) for the history and types of $k$ ?n?nn?mes. For collections of Ottoman $k$ ? $n$ ?nn?mes, see Barkan (1943), Akg?nd?z (1990), and the bibliography in the appendix of Howard (1995/96). 5 ?nalc k (1954b), ?nalc ?k (1994: Chapter 5).

${ }^{6}$ The oldest available defter in Turkish archives is that of Albania, dated 1431-32, which has been edited by ?nalc $\mathrm{k}$ (1954a). Although the practice of carrying out new surveys of the tax revenues of previously conquered lands became uncommon after the sixteenth century, the Ottomans continued to prepare new defters of newly conquered or reconquered lands in the seventeenth century. For an example of such late defters, see the description of the defter of Kamani?e, dated 1681, by Kolodziejczyk (1993).

${ }^{7}$ The importance of these defters for historical scholarship has even led to the creation of a methodological sub-discipline called "Defterology" and Tahrir studies (for example, Barkan, 1970b; Cvetkova, 1983; Halasi-Kun, 1986; Lowry, 1992; Singer, 1990; and the 1993 issue of The Journal of Ottoman Studies). There have also been three international congresses (Defter 
publications in this genre generally had modest objectives with mere transcriptions of the data and little or no analysis, some of the recent studies have also included more sophisticated analysis of taxation, population, and production trends in a region.

In a parallel genre, studies have analyzed, rather than publish in raw form, the data from defters for a variety of purposes. These studies have variously taken advantage of the wealth of information contained in these registers by examining, for example, the names, religions, and marital status of the taxpayers and the amount and composition of agricultural production in a region. Numerous books, articles, and Ph.D. dissertations have been written that have used a single or a series of registers to study the social and economic history of a certain region in great detail.

Despite the recent proliferation of studies based ondefters, it is interesting that the full potential of these documents has not been realized. These studies often restrict the scope of their inquiry to regional history, typically shying away from questions with broader (such as comprehensive or comparative) geographic importance. They similarly determine their scope more by the parameters of the documents than by the important questions of historical and socioeconomic inquiry. As a consequence, they do not sufficiently engage in creative exercises such as standardizing data across regions by identifying variations in weights and measures, interpreting data beyond their original bureaucratic definitions, generating new variables by making reasonable assumptions, and extracting relevant data efficiently by drawing representative samples. ${ }^{8}$ I argue below that there have been two general reasons for these

Congresses, the first two in Konya, Turkey and the third in Erlangen, Germany) dedicated solely to the discussion of how best to proceed in the publication and use of defters.

${ }^{8}$ Well-known, if not uncontroversial, exceptions to these tendencies include Barkan's (1953) estimation of population, McGowan's (1969) study of food supply and taxation, and H?tteroth and Abdulfattah's (1977) study of historical geography. 
tendencies: the current pessimistic attitude toward the potential of these documents as historical sources and the high cost of processing the massive amounts of data that they contain. Let me detail these issues and suggest ways of overcoming them.

\section{CRITICISMS OF THE USE OF TAHRIR DEFTERS}

Although some Hungarian researchers had brought attention to the value of, and published some excerpts from, the tahrir defters during the late nineteenth century, it was not until the Second World War that studies based on these documents began with full force. Because these documents were not yet made available for scholars' use in Turkish archives, it was Fekete's (1943) publication of a defter (of the Hungarian district of Esztergom [Ostrogon]) that was preserved in Berlin which pioneered the genre of editing (with transcription and/or translation) whole registers. ${ }^{9}$ The next few decades witnessed numerous pioneering contributions to the field. Impressive results were achieved following the increasing openness of Turkish archives to researchers and the commitments by both Turkish authorities and an international group of scholars to undertake and promote tahrir studies. ${ }^{10}$ As Barkan (1970b: 163) proudly expressed, tahrir defters were viewed as "the most precious possession of the Turkish archives."

Many in the succeeding generations of scholars have shared the excitement of the masters and pursued their agenda. The registers of various other regions have been published, and the defter-based local histories of various regions have been written. Some historians have even

\footnotetext{
${ }^{9}$ For the defters of Hungarian provinces and the history of early scholarship in the field, see Fekete (1947).

${ }^{10}$ For a history of scholarship during this period, see Halasi-Kun (1986: 163-64) and Heywood (1988: 322-25). Historians' excitement about the defters was in some ways greater for the
} 
pushed the agenda further by using the data from these documents in novel ways, for example by examining urban life, population pressure, agricultural productivity, and the continuity and change between Byzantine and Ottoman institutions. ${ }^{11}$

There were, of course, various criticisms of the research based on the defters. While some of these criticisms objected to some lines of research as being too broad or too limited, others were directed against what were deemed as inappropriate interpretations or applications of the data. Researchers were cautioned against unwarranted claims and urged to incorporate other methods of inquiry and sources of data. For example, the methods employed by the early work on demographic history pioneered by Barkan have been heavily criticized, generating a literature on how to determine the value of the household-multiplier and how best to use tahrir defters in conjunction with other sources to estimate population. ${ }^{12}$ There were also general criticisms of conventional approaches to defters, seeking to promote specific complementary sources and alternative methodologies. ${ }^{13}$

Constructive criticisms are inevitable in any field of scholarship, and a healthy dose of criticism is necessary and valuable to prevent ill-advised research. Misdirected and overstated criticisms, on the other hand, run the risk of undermining or even blocking new and valuable

history of the territories controlled by the Ottomans outside of Turkey proper. See Cvetkova (1983), Fene?an (1996), Kaldy-Nagy (1968), and Lewis (1951) for examples.

${ }^{11}$ Faroqhi (1984), Cook (1972), Venzke (1997), and Bryer and Lowry (1986). See also ? z (2002) for a review of the pertinent literature and a discussion of the value of defters as quantitative sources.

${ }^{12}$ For a review of these issues and the pertinent literature, see Ataman (1986) and Faroqhi (1999: 86-95).

${ }^{13}$ For example, Heywood (1988) proposed to view defters essentially as "texts" (rather than as mere sources of quantitative data) and suggested a textual reading of them, Murphey (1990) examined the records of the Imperial council ( $m$ ?himme defterleri) to highlight the importance of understanding the process of drafting the tahrir defters, and Singer (1990) suggested ways in 
research. Although many of the criticisms of the research based on defters have similarly made undoubtedly valuable contributions to the field, there were also criticisms that may have done more harm than good, despite the good intentions of their authors. This may be the case particularly for the critical comments of respected historians, some of whose own works have otherwise pioneered research based on these registers.

Consider, as perhaps the best example of this type of phenomenon, the critical comments of Lowry (1992). ${ }^{14}$ Himself a respected scholar and well-known contributor to tahrir studies, but at some point seriously concerned about some of the misuses of these documents, Lowry set out to show the "pitfalls and limitations" of using them as sources for social and economic history. His first "dictum" begins with the statement: ${ }^{15}$ "The tahrir defters alone do not provide the basis for any kind of quantitative study, be it toponymy, topography, taxation, agricultural production, or population." Showing how the registers that he examined excluded some villages, which were then included in other sources, he suggests that all other surviving sources must also be examined for an overall perspective. Although no one would dispute the general message of this dictum (that more sources are better), the sweeping prohibition issued against "any kind of quantitative study" seems excessively restrictive. What would be wrong, to take a simple example, with a quantitative study aimed at calculating the average amount of taxes paid by the villagers to timariots (fief-holders)? Although the defters may have excluded villages that paid taxes to other recipients (such as vakfs), they most certainly included the timariots, so one need not consult any other sources for a satisfactory quantitative study of the taxes that the villages

which the court records (kad?sicilleri) can be used together with the defters of a region to study rural administration.

${ }^{14}$ Published as a chapter in Lowry (1992), this was originally a paper read by Lowry at the IV. International Congress on Turkish Economic and Social History in Munich in 1986.

${ }^{15}$ Lowry (1992: 8). Italics on "any kind of quantitative study" are mine. 
paid them. Moreover, as I will argue in more detail below, unless one had good reason to suspect systematic differences between included and excluded villages, information from the included villages (or even from a smaller subset of them) can for some types of inquiries be used as representative of the overall population. Lowry can be said to be following exactly the same strategy, after all, when he uses his knowledge of the "pitfalls and limitations" of some defters to make generalized comments on all defters.

In any case, despite the constructive dimension of Lowry's dictum and of similar comments by others of the same tone, the problem is that they are often worded much too strongly. It is one thing to make useful recommendations to others, such as to suggest the use of other relevant sources whenever it is appropriate, it is yet another to consider illegitimate those studies that have not followed the recommendation, and to make sweeping, unwarranted generalizations about research agendas as a whole. Although some of this may have been necessary to caution others against misguided research, too much of it may have also caused caution to turn into stumbling block and discouraged original new research. Coming from respected scholars, these comments will undoubtedly be taken seriously and should be reassessed and qualified for a more balanced perspective.

\section{ANSWERING THE CRITICISMS}

Underlying most concerns about the use of tahrir defters in historical research is the recognition that in conducting the surveys the Ottoman government was not always interested in gathering the same information as today's historian would have wanted. The purpose of these documents was to record only taxable resources and activities, not to survey the population, resources, or economic activities as a whole. The quality of the information was determined by 
such constraints as the availability of enumerators and other resources allocated to this process, the willingness of the villagers to cooperate with the enumerators, and various differences among regions in language, customs, and units of measurement.

None of these concerns, however, are necessarily peculiar to tahrir defters. They are fundamental difficulties faced in all areas of historical scholarship, and should thus be properly viewed as issues that we need to understand and solve to be able to keep pushing the boundaries of knowledge. In all areas of historical inquiry the usefulness and limitations of sources are determined not solely by any inherent qualities of documents but by the research questions of the historians. With this methodological principle as a guide, let us now examine the extent of the limitations of defters identified in the literature.

Upon closer inspection, some of the commonly identified limitations of these documents actually turn out to be advantageous to the historian. For example, it is often alleged as a major weakness of the defters that the recorded figures reflect assessments rather than actually collected amounts of taxes and that collected amounts could vary greatly from assessments. ${ }^{16}$ The enumerators were indeed instructed to record not the amounts of taxes collected during the year of the survey but the expected amounts based on the averages of the last three years. Given that the surveys were not done annually, however, this procedure made these amounts even more useful indicators of taxation for most historical inquiries, precisely because the collected taxes (especially the ? ?r, tithes) could vary greatly from one year to the next. Had the recorded figures been the amounts of actual taxes, historians interested in using this information to study such issues as tax burden and agricultural productivity would have had to somehow correct for the effect of temporal variations in weather and other conditions to be able to generalize the

${ }^{16}$ See, for example, Singer (1990: 102) 
results. By averaging the amounts over three years, the defters intended to factor in these variations, which made the information more reliable and useful for both the Ottomans themselves and the modern historians.

It is also seen as a limitation that the defters did not record all resources and productive activities. There were undoubtedly items that went unrecorded in the surveys, either because they were somehow hidden from the surveyors or because the surveyors chose not to record them. Although there is evidence of attempts by taxpayers to avoid registering some of their taxable activities or of registration altogether by fleeing the site, the extent of this was probably minor because the Ottomans implemented various mechanisms, such as to ensure the presence of a team of experts and local leaders along with the taxpayers, into the registration process. Similarly, although the surveyors did not record some items intentionally, the tax revenue that was thus lost must have been deemed smaller than the benefit of recording and collecting those taxes. Given the interests of the state, one would have to presume that the surveyors would have recorded any resource or activity that was important enough to tax and feasible enough to assess and record. Because the resources used in the assessment, registry, collection, distribution, and other stages of the process of taxation were subject to scarcity, intentional omission of resources and activities were more likely to reflect an efficient allocation of scarce administrative resources than a systematic failure of surveyors. ${ }^{17}$ Put differently, full information about taxable resources was not necessarily the optimal amount of information.

The absence of information on some resources and activities may be another instance of a limitation of these documents actually being advantageous to the historian. Imagine the hypothetical scenario of tahrir defters that included literally all of the resources and activities in 
a region. That would have given both the Ottoman government and today's historian an overwhelming amount of information, with a possibly prohibitively high cost of gathering, sorting out, and processing the data for use in taxation or research. Although one cannot deny the value of additional information for some research questions, for those interested in issues like production and taxation the reduction of the data to essential items may have been a mixed blessing. Given their local knowledge of the region and general knowledge of the cost of the taxation process, the surveyors were in the best position to determine which resources and activities were necessary to record. Lacking this knowledge, today's historian's determination of the same would have been with a much greater degree of difficulty and arbitrariness.

Although there are other limitations of defters without concurring advantages, it is nevertheless possible to overcome these limitations with further research. Perhaps the severest limitation is the incompleteness of the information about inhabitants. Because in conducting the surveys the Ottoman government was concerned primarily with taxation, the enumerators typically recorded only tax-paying adult males, omitting women, children, and tax-exempt groups. ${ }^{18}$ Studies of Ottoman population based on these registers, therefore, have had to find ways of making up for the missing information. Early studies commonly relied on simple measures like the household multiplier in estimating total population from available information. Despite being based on an acceptable basic methodology, these early studies have been highly criticized for their speculative ways of determining the values of multipliers. These criticisms, however, cannot be the basis for dismissing the whole project altogether. Although the pioneers may have been mistaken to use merely educated guesswork to estimate the multipliers, we can

${ }^{17}$ It is also possible, of course, that some of this omission results from rent seeking, negotiation, and compromise between state and taxpayers. See Murphey (1995/96). 
now advance their contributions by more sophisticated, collaborative studies that use recent demographic theories and a variety of sources complementary to tahrir defters, such as those proposed by Ataman (1992). This is precisely how progress is achieved in scientific inquiry, and studies of Ottoman population based on defters should be no exception.

Regional differences in units of measurement also present a set of limitations that can be similarly overcome by further research. Units for measuring weights and capacity could vary significantly among regions. ${ }^{19}$ Because enumerators sometimes used regional, rather than standardized, units of measurement to record the amounts of tithes due in-kind, it can be problematic to use these data for such inquiries as cross-regional comparisons of productivity. There are, however, ways of overcoming this problem. For example, one can use the value, rather than quantity, of output for comparison purposes. ${ }^{20}$ In the case of tithes, defters show both the quantity and the value of taxes, allowing the enumerator to use these values to aggregate taxes across products and taxpayers and for the historian to make legitimate comparisons based on standard currency. ${ }^{21}$ Another way of overcoming the problem is to determine the differences in units of measurement between regions by further research. Although monetary comparisons may be sufficient for most inquiries, some questions may require the researcher to determine the quantity of output, which in turn would require him or her to determine regional differences in

\footnotetext{
18 Although some defters recorded tax-exempt groups, this practice was not consistently followed in all regions.

${ }^{19}$ There could even be significant variations in the standards used within the same unit. See Venzke (1997: 45-59) for a detailed discussion of the variety of measures used in the Aleppo region. See also ?nalc k (1983) and ?nalc k (1994, Volume I: 987-93) for Ottoman weights and measures in general.

${ }^{20}$ Note also that, in cases of production involving multiple products, one has no choice but use values (instead of output) for aggregation purposes, independent of how standardized may be the unit of measuring output.
} 
units of measurement. Some of these differences have already been well documented (?nalc K

(1983; 1994, Volume I: 987-93); others can be determined by further research that uses similar methods and other sources.

None of this is meant to imply that tahrir defters are sources free of problems or that the problems should be neglected. The point is simply that these problems are neither impossible to solve, nor isolated to Ottoman tahrir defters. All sources, including modern population censuses and opinion surveys, have problems of their own, and researchers need to make use of what is available with caution and methodological rigor. Although the nature and magnitude of the problem may differ among fields of inquiry, these differences do not set apart the historian of the Ottoman Empire as being distinctly disadvantaged because of the limitations of these registers as historical sources.

Just as various imperfections of sources have not prevented progress in other fields of historical scholarship, inevitable imperfections of tahrir defters can be overcome for progress in Ottoman history. The fact remains, however, that the critical attitude toward these documents contrasts sharply with some of the more appreciative and optimistic attitude displayed toward the use of comparable sources in other literatures. Consider, for example, Kosminky's (1956) pioneering study of English agrarian history based on the Hundred Rolls of 1279. Carefully reviewing various problems about the reliability of these records, he asks: "Do not their incompleteness and patchiness, the presence of gaps and mistakes, the vague and unreal nature of many of the figures and terms of measurement, all render hopeless any attempt to obtain an accurate answer?"(p. 40) Reminding us that similar problems invariably arise in all medieval

${ }^{21}$ Values are calculated by using prices determined by the government. Although one could question the reliability of government-determined prices in reflecting market values, Pamuk (2000) finds that they exhibited similar trends. 
sources, he dismisses the question by urging the historian to choose methods that generate not necessarily precise and certain but approximate and satisfactory answers "which are unattainable by other methods of investigation." Despite acknowledging various significant limitations of using this source, he states: "the risk involved in its use is no greater than that which always arises when we cease to be satisfied with limited answers to particular questions and seek to solve a general problem as a whole." (pp. 41-42) Given that tahrir defters as a whole are arguably more reliable records than the Hundred Rolls, Kosminsky's principles of historical method have clear implications to the historian of the Ottoman Empire.

Consider also similar issues raised about the reliability of another well-known set of sources that are widely available around the world as recorded throughout history by various states and private (religious or secular) organizations: tithe records. These records have been the focus of attention in various fields of history and their reliability the subject of numerous heated debates. Despite well-known criticisms of using tithe as a source, historians have successfully used them in various creative ways for historical research, including studies of legal and institutional history of the tithe and comparative studies of productivity. Reviewing the use of tithe records in studying production and productivity, Le Roy Ladurie and Goy (1982: 31) put it well: "To be cautious is one thing; but to take refuge in overqualification and hypercriticism can 'sterilize' certain subjects by concentrating on negative conclusions." To avoid such undesirable outcomes, Ottoman historians would do well to follow the methodological advice of successful developments in parallel fields and adopt a healthier attitude toward their sources.

The basic principle should be to view limitations of documents as challenges for further research, rather than obstacles for progress. This means to move away from generalizations such as that stated by Lowry (1992: 12) as a dictum: "The tahrir defters were not intended to serve as 
comprehensive registers of population. Consequently, all studies hitherto published which attempt to extract population statistics from the raw $h$ ?ne data they provide are basically guilty of practising alchemy, i.e., trying to turn base metals into gold." Lowry appears to be confusing alchemy with metallurgy here. Even though one may not be able to turn base metals into pure gold, that is not reason enough to stop mixing metals until some useful alloy is formed. Isn't turning otherwise useless items into useful sources an indispensable component of the historian's craft? The alternative strategy implied by Lowry's dictum is curious, for it would mean to abandon all attempts at estimating Ottoman population based on defters. Although Lowry's comments may have been prompted by the perceived failures of previous scholars in demographic history, it would have been more proper to view such fields of past failures as bright paths of great challenge rather than dark alleys of blocked entrance. Wholesale limitations on the applicability of historical sources to some fields would be the same as letting documents dictate the research agenda, rather than the other way around.

\section{SAMPLING IN HISTORICAL RESEARCH}

The other problem that has burdened research based on tahrir defters is the enormity of the information. The sheer size of these documents, which may run over a thousand pages, might present an overwhelming task to the historian, testing the limits of available funds for gathering, storing, and processing the data. Compounded with other difficulties in accessing, transcrib ing, and processing these data, the size and total number of the defters force the researcher to find a feasible strategy in extracting the information.

A commonly used strategy in dealing with the enormity of data is sampling. Occasionally, it might be necessary and feasible for the researcher to gather information about 
every member of a population. For example, the only way one can determine the youngest member of a group of students might be by finding out the ages of all students in the group, which may be very easy to do in a small group of, say, 30 students. Most research questions, however, do not necessarily require information about every member of a population and often require such an overwhelming amount of information that an exhaustive data-collection is simply not feasible. Suppose you wanted to determine the mean age (or height, income, literacy rate, etc.) of all Turkish citizens in the world. Only in an ideal world with unlimited resources and unrestricted access to information would it be possible to gather the required data and base analyses on all members of this population. In a world of scarcity, however, resources must be used efficiently and researchers must obtain the required information from a representative sample of the population. The theory of sampling shows that a properly drawn sample can radically reduce the amount of work required in collecting data, without a significant loss of accuracy. For example, to obtain a reliable estimate of the mean age of all Turkish citizens, it might be sufficient to gather the information from a small sample of individuals chosen randomly in a representative community in Turkey.

Sampling has played a significant role in historical research. Some sources of historical information include massive amounts of data, such as those contained in the enumeration schedules of population censuses, probate inventories, and certificates of birth, death, and marriage. One way the historians have been able to deal with the problem of massive amounts of data has been to restrict the focus of inquiry in time, space, or subject. An alternative strategy, encouraged in an influential article by Schofield (1972) and frequently employed in a variety of contexts, is sampling. Sampling has made it possible for the historian to widen the scale and scope of inquiry by efficiently extracting information from large amounts of data. For example, 
influential studies of American history that relied on the enumeration schedules of the U.S. Censuses were based on sample data ${ }^{22}$. As an additional benefit of sampling, historians have often made their sample data available to other researchers in machine readable form, thereby allowing others to address issues that can be investigated using the same data. Well-known examples of such undertaking are the Parker-Gallman sample of southern farms and the Bateman-Foust sample of northern farms in the U.S., both based on the agriculture and population censuses of 1860 .

Ottoman historians have also employed sampling in their research, though perhaps less explicitly and less systematically. Quantitative studies, such as the measurements of changes in prices, economic activity, and population levels, have often relied on sample data. For example, Barkan (1970a) and Pamuk (2001) studied the price revolution of the sixteenth century by calculating price indexes based on the prices of a representative set of leading consumption items. Rather than use the price information from each archival source about every commodity everywhere in the Empire, they simply used the information from the account books and prices paid by hospices, pious foundations (vakf), Topkap?Palace, and officially established price ceilings (narh). Some of the nonquantitative studies have also employed a sampling approach. The collection of regional law codes included in Barkan's well-known Kanunlar, for example, is only a small subset of all of the $k$ ? $n$ ?nn?mes available in the archives, a subset deemed representative of the whole. ${ }^{23}$

Similarly, studies of Ottoman consumption based on estate inventories, registers of the palace kitchen, and other written records have used sampling to collect evidence (Quataert,

\footnotetext{
${ }^{22}$ For example, Thernstrom (1973), Fogel and Engerman (1974). See also Johnson (1978) for a critique of the sampling methods of these works.
} 
2000). Although some of these studies have not been explicit enough about their choices of evidence and methods of sampling, they clearly seek to benefit from the advantages of sampling by making general claims about their subject matter, based on the presumption that their sample represents the whole. Of course, the persuasiveness of the claims ultimately depend on the representativeness of the sample, an issue that can best be answered with proper knowledge of sampling theory and methods, rather than in an ad hoc manner.

Although studies based on tahrir defters have typically used whole registers as sources, some studies have taken rare exceptions to this trend by explicitly or implicitly treating their limited geographic coverage as being representative of a larger population in order to address questions with wider theoretical or geographic focus. For example, although ?slamo ?lu?nan's (1994) study used data from the defters of part of the vil?yet of Rum (about 500 settlements), she derived conclusions about the state and peasant relations in Anatolia as a whole, based on an implicit belief about the representativeness of this region for Anatolia. Similarly, demographic studies have typically used the defters of specific regions to determine more general population trends. For example, Barkan's (1970b) pioneering estimates of the Ottoman population used data from only cities and towns, with the following justification: "with certain qualifications one can accept the hypothesis that in this period the growth of the urban population was closely related to the growth of the total population." Similarly, Cook's (1972) study of population pressure in rural Anatolia used evidence from three areas of Anatolia (about 700 villages). Showing Braudel's well-known hypothesis of increasing population pressure as being applicable to these areas, he then broadened the domain of inquiry and asked: "supposing the hypothesis were true, not just of the three areas studied here, but of Anatolia as a whole, what

23 But see also Lowry's (1992: Chapter 2) criticism of this. 
exactly would it explain for us?" (p. 29) Although the implicit and ad hoc nature of the sampling procedures used in some of these studies may raise questions about the completeness and reliability of their conclusions, their impact on Ottoman history nevertheless shows the way a well-chosen part can be representative of the whole.

The only case of explicit sampling of defters todate has been in McGowan's (1969) comparative study of food supply and taxation in four selected sancaks on the Middle Danube. Having studied the Sirem sancak in detail as a whole for his Ph.D. Dissertation, he added a comparative dimension to the analysis by selecting a (systematic) sample of 100 villages from each of the other three sancaks ${ }^{24}$. Using these data and simple statistical techniques, he estimated quantitative measures of productivity and standard of living to answer various socioeconomic questions in a comparative setting.

One of the reasons why researchers did not follow McGowan's lead in sampling the defters for quantitative analysis may have been the ad hoc nature of his sampling procedure and the lack of detailed discussions of alternative sampling procedures, the size and representativeness of the selected samples, and the cost and benefits of sampling in general. Stating sampling as being "one of the great labor saving benefits of modern statistical techniques," he me rely asserts that "random samples of 100 are sufficiently large to warrant generalization.” (p. 152) Similarly, although he uses a page-oriented systematic sampling procedure, he expresses hope that "this method would result in a random spatial dispersion throughout each province." (p. 152, emphasis added) He does not discuss in detail where the number 100 came from and whether his sampling procedure really resulted in a random dispersion. In fact, because the probabilities of being drawn into the sample differ significantly

${ }^{24}$ See McGowan (1969: 152) for a description of the sampling procedure. 
between systematic and random methods of sampling, the properties of estimates are not the same under the two methods. This does not mean, of course, that McGowan's sampling procedure was erroneous or that his arguments were unpersuasive. It only means that a more satisfactory discussion of these issues would have made his method of sampling more acceptable, his arguments even more persuasive, and possibly sampling in general a more common practice among the historians of the Ottoman Empire.

\section{METHODS OF SAMPLING}

To discuss the procedures and relative advantages of different methods of sampling, let us focus on three widely used methods that are most applicable to sampling the tahrir defters: random, systematic, and cluster sampling ${ }^{25}$. As discussed earlier, the essential point in sampling is that the chosen sample must be able to represent the variability of the population. Because human beings choosing deliberately are likely to introduce bias, an acceptable method must avoid deliberate choice and use an unbiased procedure for the sample to be representative. Although the three methods chosen for illustration are all acceptable and widely used in survey research, each has distinct advantages and disadvantages.

An ideal procedure of selection gives each item an equal chance of being included in the sample. The method that best meets this criterion is simple random sampling, which leaves selection entirely to chance. If a numbered list of all the items in the population are available, choosing randomly means to use only a table of random digits or some other appropriate random mechanism for selection from the list. For example, if one can make a complete list of all the

25 See Levy and Lemeshow (2000) or other textbooks on sampling for details on these methods and on other sampling methods available to researchers. Because the structure of population in 
villages in a tahrir defter arranged in numerical order (e.g., in the order they are listed in the document), the random number generator of a computer can be used to determine the subset of the villages to be included in the sample.

Although random sampling has many desirable properties, investigators often prefe r nonrandom methods of sampling, because it is often very costly or impossible to make a complete list of all the items in the population before sampling can begin. Even when a list might be easily available, it might be too tedious and time consuming to access randomly chosen items in the data source. In sampling a tahrir defter, for example, villages may not be numbered consecutively throughout the document, or they might be listed mixed with other types of administrative units (e.g., urban districts and uninhabited villages), in which cases one would have to number the villages. Note also that under the current rules of Turkish archives researchers are allowed to photocopy only one-third of a defter. One would thus have to work with the original document in drawing a list. Because one would not be allowed to write on an original document, however, one would have to draw a separate list with the names and locations of villages in the defter and then return to the original document once the sample is chosen in order to locate and record detailed data for the villages in the sample. These considerations may make the method of random sampling a tedious and difficult procedure for sampling these documents.

Another widely used method is systematic sampling, where every $\mathrm{k}^{\text {th }}$ item is drawn sequentially from the population. Systematic sampling is likely to be much easier and cheaper to administer than random sampling, because it requires counting only as the sample is drawn. In cases where numerical ordering of the population is difficult or impossible prior to sampling tahrir defters does not fall into natural, easily identifiable and relevant stratifications, stratified 
(e.g., when working with original documents), it would thus be more convenient to use systematic sampling. As discussed above, McGowan (1969) applied the systematic (rather than random) method in sampling the tahrir defters by using a page-oriented selection procedure.

In systematic sampling, once the first item has been selected, the rest of the sample is determined, so all items do not have an equal chance of being drawn in the sample. The only possible place of random selection in systematic sampling is in the choice of the first entry, which is frequently chosen by generating a random number between 1 and $\mathrm{k}$. Systematic and random sampling procedures thus have comparable properties only if the items in the population were listed in a random order. If, however, there is an unknown periodicity, a relationship between every $\mathrm{k}^{\text {th }}$ item in the arrangement of the items in the population, then systematic sample will be biased and its results unreliable.

Another widely employed method is cluster sampling, which consists of grouping sampling units into clusters on a spatial or geographical basis, sampling these clusters at random, and either selecting all of the units in the cluster or sampling them at higher than usual rates (sometimes further subsampling the chosen cluster in multiple stages of cluster sampling). This method has been frequently employed, for example in sampling the U.S. Census manuscript schedules. Because the villages in tahrir defters were already clustered into larger divisions called $n$ ?hiyes, cluster sampling these villages would mean to randomly select one (or more) of the $n$ ?hiyes and either selecting all of the villages in the $n$ ?hiye or (randomly, systematically, or by another method) selecting a smaller subset of them, depending on the desired size of the sample. Cluster sampling thus does not have the desirable properties of random sampling and is likely to be problematic if variations within clusters are much less than between clusters.

sampling methods are omitted in this discussion. 
Although other sampling methods might produce better estimators of population characteristics, cluster sampling is nonetheless widely employed in survey research primarily because it offers greater administrative convenience, lower sampling costs, and easier access to source data.

How large a sample is needed? Determining the required sample size is one of the most important problems that a researcher has to decide in order to obtain reliable estimates of population characteristics. Although a larger sample would clearly increase the accuracy of the estimates of population parameters, it would also be costlier. In general, the choice of a sampling size may involve a complex set of considerations including the preferred sampling method, cost of sampling, the desired level of the reliability of estimators, and information about the (usually unknown) population parameters. It also depends on the population characteristics of interest: whether one is interested in estimating a total, median, proportion, or mean value.

Suppose, for example, that our objective is to use a simple random sample to estimate the mean value of a single population characteristic, such as the mean age or income level of individuals in a city. Assuming sampling costs to be directly proportional to sample size, the minimum desired sample size can be approximated by the formula:

$\mathrm{n}_{\mathrm{o}} ?\left(\mathrm{z}^{2} ?^{2}\right) / \mathrm{d}^{2}$

where $\mathrm{z}$ is the reliability coefficient corresponding to the specified confidence level (based on a normality assumption for sampling distribution of the estimate), ${ }^{2}$ is the (typically unknown) population variance, and ? is the value set by the investigator for the maximum acceptable difference between the sample estimate and true population parameter $^{26}$. We see from this

\footnotetext{
${ }^{26}$ Various procedures, such as relying on pilot studies or previous surveys, can be used to estimate unknown population variance. The acceptable sample size is different for other statistics of interest and methods of sampling. See, for example, Schofield (1972) and Levy and Lemeshow (2000) for details and illustrations of how to determine the optimal sample sizes.
} 
formula that the smaller we choose ?, the greater will be the sample size. Similarly, the optimal sample size will rise with higher values of $\mathrm{z}$ and ? .

If $n_{0}$ turns out to be a high fraction of the whole population, it can be reduced by the finite population correction through the following formula:

$\mathrm{n}=\mathrm{n}_{\mathrm{o}} /\left[1+\left(\mathrm{n}_{\mathrm{o}} / \mathrm{N}\right)\right]$

where $\mathrm{N}$ is the total number of items in the population.

\section{POPULATION CHARACTERISTICS AND THEIR ESTIMATES}

To illustrate these procedures with simple examples and to show the advantages of sampling, I use data from the published defters of Antep, Budun, Jerusalem, and Malatya ${ }^{27}$. These regions represent the geographic diversity of the Ottoman Empire: Budun is in southeastern Europe, Jerusalem is in southwestern Asia, and Antep and Malatya are in Asia Minor. Moreover, because some of these publications cover a series of registers, they provide information about these regions at different periods of time. The dates (CE) of these defters are 1536, 1543, and 1574 for Antep; 1546 and 1562 for Budun; 1596 for Jerusalem; and 1560 for Malatya. I use these data first to calculate summary statistics for all villages (whole population) recorded in a defter, separately for each region and time period. I then use the three sampling methods described above to draw samples from each defter, use these samples to estimate the characteristics of populations, and compare the results of different estimation methods with each other and with population values.

Suppose for illustration purposes that our objective is to estimate two characteristics of the villages recorded in these documents, two mean values chosen to represent different levels of 
variability among villages ${ }^{28}$. The first is the mean value of taxes due from cereal grains (sum of all taxes due from wheat, barley, millet, etc.). Because most villages grew cereals, the variability of taxes from cereals was low among villages, as can be seen in the Appendix from the low standard deviation of cereals (relative to the mean) in most regions ${ }^{29}$. The second characteristic of interest is the mean value of taxes due from fruits and vegetables (the sum of all--variously termed--taxes due from the products of gardens, orchards, and vineyards). A comparison of the standard deviations (relative to means) of taxes reported in the Appendix show that villages must have grown much more variable amounts of fruits and vegetables than cereal grains. Different levels of variability between the two types of taxes will show the way benefits of sampling can vary with the characteristic of interest.

As discussed above, the optimal sample size depends on the method of sampling, population characteristics of interest, the desired level of the reliability of estimators, and population variance. For simple random samples, I used the above formula to determine the sample size. I first determined the minimum acceptable sample size corresponding to a wide level of reliability of 20 percent. That is, I chose ? such that the sample estimate should not differ from the population mean by more than 20 percent (that is, ? $=0.2 ?_{\mathrm{x}}$, where $?_{\mathrm{x}}$ is the population mean for characteristic $\mathrm{x}$ ) and I chose $\mathrm{z}=1.645$, the $\mathrm{z}$-value corresponding to the confidence level of 20

27 ? zde?er (1988), Kaldy-Nagy (1971), H?tteroth and Abdalfattah (1977), and Yinan? and Elib?y?k (1983).

${ }^{28}$ In general, as can be seen in the Appendix, the defters include information about the number of adult male taxpayers, the peasant family tax (?ift resmi) and taxes on cereals, legumes, rice, fruits and vegetables, beehives, animals, mills, the badihava tax, and other miscellaneous taxes. ${ }^{29}$ Formally, variability is measured by the coefficient of variation (or its square: relative variance), which is equal to the ratio of standard deviation to mean. 
percent ${ }^{30}$. Once I determined the required sample size $\mathrm{n}$ for these conventional but wide levels of reliability, I also generated samples of sizes $1.5 \mathrm{n}$ and $2 \mathrm{n}$ to illustrate the sensitivity of results to variations in sample size beyond $\mathrm{n}$.

I used the optimal size calculated for simple random samples to approximate the size of systematic samples. I can assume that villages were listed in defters in a random (non-periodic) order, so the situation is practically the same as simple random sampling. Because the size of a systematic sample also depends on the sampling interval, it can only approximate the desired size. For example, if the formula happens to generate 42 as the desired sample size from a region of 200 villages, this size can be approximated by a 1 in 5 systematic sample that yields 40 villages. Similar to simple random samples, once I determined $\mathrm{n}$ this way, I also generated systematic samples of sizes $1.5 \mathrm{n}$ and $2 \mathrm{n}$ to observe the role of increasing size.

I generated two types of cluster samples. The first is based on random selections of subprovinces, called $n$ ?hiye, within each region. I first randomly chose one of the $n$ ?hiyes. If the total number of villages in this $n$ ?hiye was large enough (that is, greater than $\mathrm{n}$ ), I included all of the villages in this $n$ ?hiye in the sample. If the number was not large enough, I chose another

${ }^{30}$ Because we have data for the whole population, I was able to calculate the population mean and variance and substitute for ? and ? in these formulas. Of course, the population parameters are typically unknown, in which case the investigator has to estimate them with pilot samples or make educated guesses about them based on previous studies. See Schofield (1972: 163-65) for examples. See also the Appendix for the population means and standard deviations of various characteristics of villages in the tahrir defters of the regions examined here, which future researchers can combine with other available information to use as guides in estimating population parameters in other regions. 
$n$ ?hiye until a sufficiently large sample was drawn. ${ }^{31}$ The sizes of this type of cluster samples were thus determined primarily by the number of villages in the chosen clusters.

For the second type of cluster samples, I chose one-third of the villages (in consecutive order) in the population. The motivation for this type of sampling is the current rule of Turkish archives of providing researchers a photocopy of only one-third of a defter. The administrative simplicity of cluster sampling might prompt a researcher to seek to achieve the benefits of sampling within the bounds of this rule simply by drawing a sample that consist of all villages in a "randomly" chosen one-third of a defter. To draw such a sample, I first chose a random number between 1 and $\mathrm{N}$ (population size) and selected the next (1/3)N villages for the sample, continuing from the beginning of the order if the sample was not completed when $\mathrm{N}$ was reached. By including such samples in the analysis we are able compare the results and assess the appropriateness of this type of a sampling procedure.

Tables 1 and 2 show estimation results separately for the taxes on cereal grains and on fruits and vegetables. In the first column of both tables are the population means, standard deviations, and the total numbers of villages in the provinces on the specified dates of the registers. Other columns show the estimates of the population means, along with the standard errors and sample sizes of the estimates, based on simple random, systematic, and cluster samples.

The means of simple random and systematic samples are generally very close to population values. Although in some cases the sample means may appear to differ substantially from population values, this difference needs to be considered in light of the standard deviations of the

31 Although I could have used two-stage cluster sampling to select a sample of size $\mathrm{n}$ (the optimal size for random sampling) by further sampling the cluster through random or systematic methods, I did not want the choice of a secondary sampling procedure to affect the results. The defter of Antep (1536) contained only one $n$ ?hiye, and similarly Jerusalem had only one $n$ ?hiye 
population and the sample means. Statistically speaking, what matters is not the absolute difference between the population and sample means but its statistical significance. To test for the significance of these differences, I calculated $t$-statistics for each sample mean. These statistics show that, at conventional levels of significance, the differences between population means and estimates obtained by simple random and systematic methods are generally statistically insignificant. One can also see in the tables that seemingly substantial differences between the population mean and its estimates typically correspond to cases where the population variance is high. A high variance of the population mean indicates a wide dispersion of values in the population, so a subsample of the population is also likely to reflect this dispersion through a high sampling error. Substantial differences between sample and population means is not necessarily a problem of sampling but a problem of distribution.

The estimates obtained by cluster sampling, however, sometimes vary significantly from the population means. The two methods of cluster sampling can also yield very different estimates, as can be seen from the estimates obtained from the Antep (1543) population in Table 1 and the Budun $(1546,1562)$ populations in Table 2. These differences are clearly indicative of substantial systematic variations among the subprovinces of a region, possibly caused by the climate, topography, and other natural and socio-economic considerations. In such cases, because cluster samples as a rule include villages from some subprovinces but not others, they do not accurately represent the population. Therefore, when one suspects such systematic differences within a region of interest, it would not be appropriate to choose cluster sampling.

A comparison of optimal sample sizes for the simple random method (n) in Table1 with the total number of villages $(\mathrm{N})$ in each region shows the benefits of sampling and the way sampling with a sufficiently large number of villages, so in those cases I randomly picked 30 and 52 
can cut the cost of collecting data by a significant fraction. The average optimal sample size in Table 1 is about 46 villages, sizes ranging from 30 in Antep in 1536 to 67 in Malatya in 1560. The proportion of optimal sample sizes to the total number of villages in the population ( $\mathrm{n} / \mathrm{N})$ range from being 10 percent of the population in Malatya to 29 percent in Antep in 1536, averaging about 16 percent in all regions. Comparing the estimates derived from samples of sizes $\mathrm{n}, 1.5 \mathrm{n}$ and $2 \mathrm{n}$, we also see that increasing the sample size beyond the optimal level does not necessarily increase the precision of estimates significantly. These figures indicate that an investigator need not have data on all villages or on a substantial proportion of villages in a region to be able to examine the history of the region.

Sample sizes in Table 2, however, show the limits to the benefits of sampling. The primary difference between the two tables is that the population variances (relative to means) are significantly greater in Table 2 than in Table 1 . As a result, the optimal sample sizes in Table 2 (with the same levels of reliability as in Table 1) are significantly higher. The average optimal sample size in Table 2 is about 130 villages, and the average proportion of optimal sample sizes to the total number of villages in the population is about 45 percent. A comparison of the two tables thus shows when sampling is most likely to be useful. Clearly the less variable are the population items, the lower has to be the optimal size of a representative sample and the greater will be the benefits of sampling. If, however, an investigator is focused on a characteristic with widely dispersed values and thus a high variability, a representative sample will have to be larger and the benefits of sampling will be reduced.

Some projects are thus less likely to benefit from sampling, because a sample may not reliably show the peculiarities of the data that are sometimes the historian's primary interest.

(corresponding to the optimal sizes for simple random samples) consecutive villages as clusters. 
Some items of interest might be observed too infrequently in the defters to be reliably represented by sampled data. For example, if one wishes to study cases of villages getting tax exemptions for special services, such as maintaining a bridge, performed for the state, then a sample of villages is unlikely to represent these instances reliably, simply because such instances happened (or were recorded in the defters) too infrequently. If attention is focused on the usual and typical rather than the unusual and extraordinary, then sampling will provide the information at a fraction of the cost of obtaining the data for the whole population.

\section{CONCLUSION}

Tahrir defters are the gold mines of research for the historian of the Middle East and Eastern Europe. They provide the historian with rich, detailed information about the names, numbers, and composition of taxpaying inhabitants and the amounts of taxes due from productive resources and economic activities. Despite the great potential of these documents, however, they have been surprisingly underutilized in historical research. Although a large body of work has utilized them as sources, their full potential has not yet been achieved in comprehensive quantitative studies. In this article I argue that following two courses of action may eventually change this outcome. By adopting a more optimistic attitude toward the potential of these sources and by using appropriate sampling procedures to gather data, the historian of the Middle East and Eastern Europe may promote the productive use of defters in historical scholarship and push the boundaries of our knowledge of this region significantly.

One recent tendency in Ottoman history has been to use excessive caution and adopt an unnecessarily critical attitude toward the tahrir defters as sources. Although some caution and critical inquiry may have been desirable in any research program, excessive amounts can amount 
to stifling further progress. Viewed properly, some of the perceived limitations of these documents can actually become advantages. In addition, most stated limitations are not significantly different from those of comparable documents used in other fields of historical scholarship, and it is possible to overcome these limitations with further research. It is more appropriate to view limitations as challenges to promote further research, rather than as reasons to prevent it.

Another common tendency in Ottoman history has been to follow the costly strategy of using whole defters rather than more efficiently collected samples in gathering data. Sampling would provide the historian of the Ottoman Empire with a well known and frequently employed method for dealing with the problem of massive amounts of available data. Although using whole defters may in some circumstances be a reasonable way of studying the history of a small region in great detail, the entire Middle East or Eastern Europe, or even entire Anatolia or the Arab lands cannot be studied through total processing of all the tahrir defters. For example, if one is interested in determining the crop map or the productivity change of the entire Middle East or Eastern Europe in the fifteenth and sixteenth centuries, these questions can only be answered with data from all provinces at our disposal. In a world of scarce resources, there simply are no resources that can be devoted to such a purpose. Even if resources were made available to support such a project, it would be inefficient and wasteful to use these resources for total processing of all defters, because sampling can radically reduce the cost without sacrificing reliability.

Although large projects are likely to benefit the most, cost considerations apply to projects of all sizes, and smaller projects with limited spatial or temporal focus can also benefit from sampling. For example, if one can rely on sampled data to determine the crop map of even 
a small region, one need not go through the expense of collecting data from all villages in that region. Sampling the tahrir defters can efficiently meet the data needs of most historians, whether with small or large projects. Any time and other resources that sampling can help to save must be saved for other uses. 


\section{WORKS CITED}

?? Akg?nd?z, Ahmed. 1990. Osmanl?Kanunn?meleri ve Hukuk?Tahlilleri. ?stanbul: Osmanl? Ara?t?malar?Vakf?

?? Ataman, Bekir Kemal. 1992. "Ottoman Demographic History (14th-17th centuries): Some Considerations," Journal of the Economic and Social History of the Orient 35:187-98.

?? Barkan, ? mer L?tfi. 1943. XV ve XVI. Asłlarda Osmanl??mparatorlu?unda Zirai Ekonominin Hukuki ve Mali Esaslar?. Cilt 1: Kanunlar Istanbul ? niversitesi yay?lar?hdan. Edebiyat Fak? Itesi T?rkiyat Enstit?s? Ne?riyat? Istanbul: Burhaneddin Matbaasi.

?? Barkan, ? mer L?tfi. 1953. “Tarih? Demografi' Ara?t?malar?ve Osmanl?Tarihi,” T? rkiyat Mecmuas?10: 1-26.

?? Barkan, ? mer L?tfi. 1970a. "XVI. Asr?h ?kinci yar3 hda T?rkiye'de Fiyat Hareketleri," Belleten Cilt 34, Say?136, pp. 557-607.

?? Barkan, ? mer L?tfi. 1970b. "Research on the Ottoman Fiscal Surve ys," in M. A. Cook, ed. Studies in the Economic History of the Middle East: From the Rise of Islam to the Present Day. London and New York: Oxford University Press.

?? Bryer, Anthony and Heath Lowry, eds. 1986. Continuity and Change in Late Byzantine and Early Ottoman Society. Washington, D.C.: Dumbarton Oaks Research Library and Collection, 1986.

?? Cook, M. A. 1972. Population Pressure in Rural Anatolia, 1450-1600. London oriental series, v. 27. London and New York: Oxford University Press.

?? Cvetkova, B. 1983. "Early Ottoman Tahrir Defters as a Source for Studies on the History of Bulgaria and theBalkans," Archivum Ottomanicum 8: 133-39.

?? Faroqhi, Suraiya. 1984. Towns and Townsmen of Ottoman Anatolia: Trade, Crafts, and Food Production in an Urban Setting, 1520-1650. New York: Cambridge University Press.

?? Faroqhi, Suraiya. 1999. Approaching Ottoman History: An Introduction to the Sources. Cambridge: Cambridge University Press.

?? Fekete, Lajos. 1943. Az Esztergomi Szandzs?k 1570 ? vi Ad??sszeir?sa Budapest.

?? Fekete, Lajos. 1947. "T?rk Vergi Tahrirleri," Belleten Cilt 11, Say?42, pp.299-328.

?? Fene?an, Cristina. 1996. "Research on the Tahrir Defterleri on Roumania," Osmanl? Ara?t3malar?[The Journal of Ottoman Studies] 16: 25-36.

?? Fogel, Robert W. and Stanley L. Engerman. 1974. Time on the Cross. Boston: Little, Brown.

?? Halasi-Kun, T. 1986. "Some Notes on Ottoman Mufassal Defter Studies," Journal of Turkish Studies 10:163-66.

- Heywood Colin. 1988. "Between Historical Myth and 'Mytho-history'-The Limits of Ottoman History", Byzantine and Modern Greek Studies, 12: 315-345.

?? Howard, Douglas A. 1995/95. "Historical Scholarship and the Classical Ottoman K?n?nn?mes," Archivum Ottomanicum 14: 79-107.

?? H?tteroth, Wolf Dieter and K. Abdalfattah. 1977. Historical Geography of Palestine, Transjordan and Southern Syria in the Late 16th Century Erlanger Geographische Arbeiten, Vol. 5, Erlangen. 
?nalc k, Halil. 1954a. Hicri 835 Tarihli Suret-i Defter-i Sancak-?Arvanid, Turk Tarih

Kuruma yayinlarindan, 14. seri, no. 1: Tahrir defterleri, Ankara: T?rk Tarih Kurumu Basimevi.

?? ?nalc k, Halil. 1954b. "Ottoman Methods of Conquest," Studia Islamica II: 103-130.

?? ?nalc k, Halil. 1960. “K?n?nn?me,” Encyclopedia of Islam, Second Edition.

?? ?nalc k, Halil. 1983. "Introduction to Ottoman Metrology," Turcica XV: 311-48.

?? ?nalc k, Halil. 1994 [with Donald Quataert]. An Economic and Social History of the Ottoman Empire, 1300-1914. NY: Cambridge University Press.

?? ?slamo?lu-?nan, Huri. 1994. State and Peasant in the Ottoman Empire: Agrarian Power Relations and Regional Economic Development in Ottoman Anatolia During the Sixteenth Century. New York: E.J. Brill.

?? Johnson, R. Christian. 1978. "A Procedure for Sampling the Manuscript Census Schedules," Journal of Interdisciplinary History 8(3): 515-30.

- Kaldy-Nagy, Gyula. 1968. "The Administration of the Sanjaq Registrations in Hungary," Acta Orientalia Academiae Scientiarum Hungaricae, 21: 181-223.

?? Kaldy-Nagy, Gyula. 1971. Kanuni Devri Budin Tahrir Defteri (1546-1562) Ankara: Ankara ? niversitesi Dil Tarih-Co?rafya Fak?ltesi Yay?lar?No. 77.

?? Kolodziejczyk, Dariusz. 1993. "The Defter-i Mufassal of Kamani?e from ca. 1681- an Example of Late Ottoman Tahrir. Reliability, Function, Principles of Publication," Osmanl? Ara?t?malar?[The Journal of Ottoman Studies] 13: 91-98.

?? Kosminsky, E. A. 1956. Studies in the Agrarian History of England in the Thirteenth Century. Oxford: Basil Blackwell.

?? Le Roy Ladurie, Emmanuel and Joseph Goy. 1982. Tithe and Agrarian History from the Fourteenth to the Nineteenth Centuries. Cambridge: Cambridge University Press.

?? Levy, Paul S. and Stanley Lemeshow. 2000. Sampling of Populations: Methods and Aplications. Third Edition. New York: John Wiley and Sons, Inc.

?? Lewis, Bernard. 1951. "The Ottoman Archives as a Source for the History of the Arab Lands," Journal of the Royal Asiatic Society 3-4: 139-55.

?? Lowry, Heath W. 1992. Studies in Defterology. Istanbul: The Isis Press.

?? McGowan, Bruce. W. 1969. "Food Supply and taxation on the Middle East Danube (15681579)," Archivum Ottomanicum 1: 139-96.

?? Murphey, Rhoads. 1990. "Ottoman Census Methods in the Mid-sixteenth Century: Three Case Histories," Studia Islamica 71: 115-26.

?? Murphey, Rhoads. 1995/96. “The Conceptual and Pragmatic Uses of the 'Summary' (Idjmal) Register in Sixteenth Century Ottoman Administrative Practice," Archivum Ottomanicum 14: 111-31.

?? Öz Mehmet 2002. "Tahrir Defterlerindeki Sayisal Veriler,” in Halil Inalcik ve Sevket Pamuk, eds. Osmanlilarda Bilgi ve Istatistik. Ankara : Devlet ?statistik Enstit?s?.

?? ? zde?er, H?seyin. 1988. Onalt hci As?rda Ay htab Livas??stanbul.

?? Pamuk, ? evket. 2000. A Monetary History of the Ottoman Empire. New York : Cambridge University Press. 
?? Pamuk, ? evket. 2001. "The Price Revolution in the Ottoman Empire Reconsidered," International Journal of Middle East Studies 33: 69-89.

?? Quataert, Donald, ed. 2000. Consumption Studies and the History of the Ottoman Empire, 1550-1922: An Introduction. Albany, NY: SUNY Press.

?? Schofield, Roger S. 1972. "Sampling in Historical Research," in Edward A. Wrigley, ed. Nineteenth C. Society: Essays in the Use of Quantitative Methods for the Study of Social Data. Cambridge: Cambridge University Press.

- Singer, Amy. 1990. "Tapu Tahrir Defterleri and Kad?Sicilleri: A Happy Marriage of Sources," Tarih: a Volume of Occasional Papers in Near Eastern Studies 1: 95-125.

?? Thernstrom, Stephan. 1973. The Other Bostonians: Poverty and Progress in the American Metropolis, 1880-1970. Cambridge, MA: Harvard University Press.

?? Venzke, Margaret L. 1997. "The Ottoman Tahrir Defterleri and Agricultural Productivity," Osmanl?Ara?t?rmalar?[The Journal of Ottoman Studies] 17: 1-61.

?? Wrigley, Edward A. and Roger S. Schofield. 1981. The Population History of England, 1541-1871 : A Reconstruction. Cambridge, MA: Harvard University Press.

?? Yinan?, Rafet and Mesut Elib?y?k, 1983. Kanuni Devri Malatya Tahrir Defteri (1560) Ankara. 


\section{Table 1 \\ Taxes due from Cereal Grains: \\ Population Values and Their Estimates}

\begin{tabular}{|c|c|c|c|c|c|c|c|c|c|c|}
\hline \multirow{2}{*}{$\begin{array}{l}\text { Region } \\
\text { (Date of defter) } \\
\text { Antep (1536) }\end{array}$} & & \multirow{2}{*}{$\begin{array}{l}\begin{array}{l}\text { Whole } \\
\text { Population }\end{array} \\
1298\end{array}$} & \multirow{2}{*}{$\begin{array}{r}\mathbf{n} \\
1154\end{array}$} & \multirow{2}{*}{$\begin{array}{r}\mathbf{1 . 5 n} \\
1190\end{array}$} & \multirow{2}{*}{$\begin{array}{r}\mathbf{2 n} \\
1386\end{array}$} & \multirow{2}{*}{$\begin{array}{r}\text { ? n } \\
1321\end{array}$} & \multirow{2}{*}{$\begin{array}{r}\text { ?1.5n } \\
1265\end{array}$} & $? 2 \mathrm{n}$ & hy & $1 / 3$ \\
\hline & Mean Value & & & & & & & 1193 & 1120 & 1353 \\
\hline & Standard Deviation & 1026 & 521 & 635 & 726 & 731 & 698 & 549 & 890 & 1112 \\
\hline & Sample Size & 102 & 30 & 44 & 59 & 25 & 34 & 51 & 44 & 34 \\
\hline \multirow[t]{3}{*}{ Antep (1543) } & Mean Value & 3821 & 3668 & 3937 & 3771 & 4005 & 3843 & 3757 & 4865 & 2142 \\
\hline & Standard Deviation & 3540 & 2716 & 2983 & 2289 & 3473 & 2921 & 2411 & 4016 & 1399 \\
\hline & Sample Size & 220 & 46 & 69 & 92 & 44 & 73 & 110 & 98 & 73 \\
\hline \multirow[t]{3}{*}{ Antep (1574) } & Mean Value & 4185 & 3893 & 4355 & 4072 & 3939 & 4665 & 4276 & 5275 & 4926 \\
\hline & Standard Deviation & 3159 & 2629 & 3133 & 2369 & 2957 & 3349 & 2666 & 3672 & 4066 \\
\hline & Sample Size & 212 & 32 & 49 & 65 & 30 & 43 & 71 & 95 & 71 \\
\hline \multirow[t]{3}{*}{ Budun (1546) } & Mean Value & 1820 & 1714 & 1682 & 1675 & 1698 & 1969 & 1618 & 1585 & 2104 \\
\hline & Standard Deviation & 1580 & 1171 & 983 & 1114 & 1121 & 1899 & 1120 & 1460 & 1827 \\
\hline & Sample Size & 297 & 43 & 65 & 87 & 42 & 59 & 99 & 73 & 99 \\
\hline \multirow[t]{3}{*}{ Budun (1562) } & Mean Value & 3164 & 3351 & 2850 & 3105 & 2801 & 3222 & 3275 & 3550 & 2905 \\
\hline & Standard Deviation & 2983 & 3176 & 2547 & 2459 & 2703 & 2403 & 2368 & 3875 & 1878 \\
\hline & Sample Size & 297 & 50 & 75 & 100 & 50 & 74 & 99 & 78 & 99 \\
\hline \multirow[t]{3}{*}{ Jerusalem (1596) } & Mean Value & 3491 & 3789 & 3276 & 3434 & 3810 & 3646 & 3275 & 2963 & 2886 \\
\hline & Standard Deviation & 3595 & 4235 & 3216 & 3767 & 3881 & 3718 & 3319 & 2364 & 2284 \\
\hline & Sample Size & 187 & 52 & 77 & 103 & 47 & 63 & 94 & 52 & 62 \\
\hline \multirow[t]{3}{*}{ Malatya (1560) } & Mean Value & 2252 & 2183 & 2513 & 2193 & 2533 & 2127 & 2286 & 1968 & 2637 \\
\hline & Standard Deviation & 2371 & 1814 & 2228 & 2078 & 3083 & 1762 & 1915 & 1630 & 2489 \\
\hline & Sample Size & 640 & 67 & 100 & 134 & 64 & 92 & 128 & 84 & 213 \\
\hline
\end{tabular}

Notes: All monetary values are expressed in the Ottoman currency of $A k ? e . \mathrm{n}$ is the minimum required size for simple random sampling corresponding to the population mean and standard deviations of each region and for twenty percent level of reliability. The sizes of systematic samples are approximated with reference to $n$. See the text for the calculation of $\mathrm{n}$ and for the description of sampling procedures.

Sources: ? zde? er (1988), Kaldy-Nagy (1971), H?tteroth and Abdalfattah (1977), and Yinan? and Elib?y?k (1983). 
Table 2

Taxes due from Fruits and Vegetables:

Population Values and Their Estimates

\begin{tabular}{|c|c|c|c|c|c|c|c|c|c|c|}
\hline \multirow[b]{2}{*}{$\begin{array}{l}\text { Region } \\
\text { (Date of defter) }\end{array}$} & & \multirow[b]{2}{*}{$\begin{array}{l}\text { Whole } \\
\text { Population }\end{array}$} & \multicolumn{3}{|c|}{ Simple Random Samples } & \multicolumn{3}{|c|}{ Systematic Samples } & \multicolumn{2}{|c|}{$\frac{\text { Cluster Samples }}{\mathbf{B y}}$} \\
\hline & & & $\mathbf{n}$ & $1.5 n$ & $2 n$ & $? \mathbf{n}$ & $? 1.5 n$ & $? 2 \mathrm{n}$ & $\begin{array}{c}\text { By } \\
N ? \text { hiye }\end{array}$ & $1 / 3$ \\
\hline \multirow[t]{3}{*}{ Antep (1536) } & Mean Value & 1653 & 1299 & 1528 & & 1462 & & & 1789 & 1489 \\
\hline & Standard Deviation & 2520 & 1353 & 705 & & 1711 & & & 2148 & 2129 \\
\hline & Sample Size & 102 & 62 & 92 & & 51 & & & 44 & 34 \\
\hline \multirow[t]{3}{*}{ Antep (1543) } & Mean Value & 2097 & 1932 & 2062 & 2146 & 2172 & 1931 & 2248 & 1595 & 1673 \\
\hline & Standard Deviation & 3071 & 2276 & 2008 & 1496 & 3264 & 2447 & 2107 & 1761 & 2497 \\
\hline & Sample Size & 220 & 87 & 131 & 174 & 55 & 73 & 110 & 98 & 73 \\
\hline \multirow[t]{3}{*}{ Antep (1574) } & Mean Value & 2361 & 2441 & 2258 & 2241 & 2415 & 2144 & 2300 & 1903 & 2342 \\
\hline & Standard Deviation & 2926 & 2444 & 2132 & 1779 & 2263 & 2280 & 1949 & 2134 & 3228 \\
\hline & Sample Size & 212 & 70 & 104 & 139 & 53 & 71 & 106 & 94 & 71 \\
\hline \multirow[t]{3}{*}{ Budun (1546) } & Mean Value & 682 & 688 & & & 887 & & & 1123 & 394 \\
\hline & Standard Deviation & 2001 & 1156 & & & 1848 & & & 3050 & 758 \\
\hline & Sample Size & 297 & 197 & & & 149 & & & 73 & 99 \\
\hline \multirow[t]{3}{*}{ Budun (1562) } & Mean Value & 1708 & 1951 & & & 1835 & & & 2545 & 759 \\
\hline & Standard Deviation & 6060 & 3518 & & & 4981 & & & 6538 & 1520 \\
\hline & Sample Size & 297 & 220 & & & 149 & & & 78 & 99 \\
\hline \multirow[t]{3}{*}{ Jerusalem (1596) } & Mean Value & 2547 & 2567 & 2526 & 2528 & 2701 & 2528 & 2564 & 4124 & 3699 \\
\hline & Standard Deviation & 4124 & 3796 & 4097 & 4445 & 4127 & 4445 & 4164 & 6307 & 5868 \\
\hline & Sample Size & 187 & 93 & 91 & 94 & 136 & 94 & 182 & 52 & 62 \\
\hline \multirow[t]{3}{*}{ Malatya (1560) } & Mean Value & 498 & 424 & 498 & 488 & 453 & 537 & 470 & 706 & 658 \\
\hline & Standard Deviation & 960 & 652 & 730 & 596 & 819 & 698 & 689 & 1055 & 1295 \\
\hline & Sample Size & 640 & 180 & 271 & 361 & 180 & 213 & 320 & 125 & 213 \\
\hline
\end{tabular}

Notes: All monetary values are expressed in the Ottoman currency of $A k ? e . \mathrm{n}$ is the minimum required size for simple random sampling corresponding to the population mean and standard deviations of each region and for twenty percent level of reliability. The sizes of systematic samples are approximated with reference to $n$. See the text for the calculation of $\mathrm{n}$ and for the description of sampling procedures. Some estimates are omitted because the sample of required size $(1.5 \mathrm{n}$ or $2 \mathrm{n})$ would have been equal to the whole population.

Sources: ? zde?er (1988), Kaldy-Nagy (1971), H?tteroth and Abdalfattah (1977), and Yinan? and Elib?y?k (1983). 


\section{Appendix:}

Villages, Taxpayers, and Taxes in Ottoman Tahrir Defters:

Number of Villages

Number of Adult Taxpayers (Households)

Labor Tax (? Ift Resmi)

Taxes From Cereal Grains

Taxes From Legumes

Taxes From Fibers

Taxes From Fruits And Vegetables

The Beehive Tax

Animal Taxes

Mill Tax

The Badihava Tax

Miscellaneous Other Taxes

Total Taxes

\begin{tabular}{rr}
$\begin{array}{c}\text { Antep } \\
(\mathbf{1 5 3 6})\end{array}$ & $\begin{array}{c}\text { Ant } \\
(\mathbf{1 5 4}\end{array}$ \\
\hline 102 & 220
\end{tabular}

30
$(38)$

(38)

$$
608
$$

$$
1298
$$$$
\text { (1026) }
$$$$
\begin{array}{r}
46 \\
(151)
\end{array}
$$$$
(151)
$$

$608 \quad 813$

(920)

$$
3821
$$$$
\text { (3540) }
$$$$
37
$$$$
\text { (171) }
$$

$$
\text { (293) }
$$

$$
1653 \quad 2097
$$$$
\text { (2520) }
$$

$$
\text { (3071) }
$$

$\begin{array}{ll}30 & 69\end{array}$

(72)

69

(96)

$$
\text { (99) }
$$

16

(30)

$94-2$

(114)

(271)

7

(75)

3814

$$
7143
$$

(4066)

Antep Budun Budun Jerusalem Malatya

$\begin{array}{lllll}(1574) & (1546) & (1562) & (1596) & (1560)\end{array}$

$\begin{array}{lllll}212 & 297 & 297 & 187 & 640\end{array}$

$\begin{array}{rrrrr}41 & 12 & 26 & 35 & 38 \\ (56) & (11) & (20) & (37) & (41) \\ & & & & \\ 908 & 606 & 1547 & & 659 \\ (936) & (557) & (1155) & & (687) \\ 4185 & 1820 & 3164 & 3491 & 2252 \\ (3159) & (1580) & (2983) & (3595) & (2371) \\ 27 & & 42 & & 1 \\ (98) & & (71) & & (15) \\ & 2 & 77 & & 251 \\ & (18) & (117) & & (470) \\ 2361 & 682 & 1708 & 2547 & 498 \\ (2926) & (2001) & (6060) & (4124) & (960) \\ 82 & 23 & 122 & 346 & 45 \\ (255) & (42) & (123) & (484) & (128) \\ 1 & 124 & 608 & 5 & 153 \\ (11) & (214) & (751) & (49) & (381) \\ 32 & 13 & 29 & 6 & 16 \\ (57) & (37) & (116) & (73) & (35) \\ 282 & 31 & 374 & 175 & 238 \\ (256) & (52) & (874) & (179) & (248) \\ 28 & 130 & 427 & 80 & 212 \\ (181) & (311) & (1561) & (577) & (1386) \\ 7910 & 3430 & 8097 & 6650 & 4324 \\ (6039) & (3394) & (10281) & (6753) & (3933) \\ & & & & \end{array}$

Notes: The numbers of taxpayers and amounts of taxes are mean values per village. Figures in parentheses are the standard deviations. All monetary values are expressed in the Ottoman currency of $A k ? e$.

Sources: ? zde?er (1988), Kaldy-Nagy (1971), H?tteroth and Abdalfattah (1977), and Yinan? and Elib?y?k (1983). 